Buana Sains Vol 20 No 1: 29 - 40, 2020

\title{
PENGARUH PUPUK KOMPOS DAN FREKUENSI PEMBERIAN MOL BONGGOL PISANG TERHADAP PERTUMBUHAN DAN PRODUKTIVITAS STROBERI (Fragaria sp.)
}

\author{
Nadhifa Hasna Fauziyah, Susilo Budiyanto dan Adriani Darmawati Sudarman \\ Program Studi Agroekoteknologi, Fakultas Peternakan dan Pertanian, \\ Universitas Diponegoro, Indonesia
}

\begin{abstract}
The aim of the study was to know the influence of the rice straw compost doses as fertilizer and the frequence microorganism local of banana weevil on the growth and yield of the strawberry. The experimental design of this research was Completely Randomize Design (CRD) factorial with three factors of rice straw compost doses (15, 20, 25 tons/ha) and three factors of frequence microorganism local of banana weevil (1 time, 3 times, and 5 times) with 3 replications. The parameter observed were bulk density of soil, porosity of soil, organic ingredients of soil, number of leaves, number of fruit, and weight of fruit. Data obtained was processed by analysis of variance and if there is an effect of yield treatment continued with Duncan multiple range test. The result showed that there are interaction between two treatment on bulk density and soil porosity. The compost doses and frequence microorganism local of banana weevil had significan effect on soil characteristic (bulk density, porosity, and organic ingredients of soil), improvement of best soil characteristic happen on compost doses 20 tons/ha and frequency microorganism local of banana weevil 2 times. Treatment of compost doses application 25 tons/ha will improve the parameters of number of leaves and number of fruit, while the best weight of fruit happen on compost doses 20 tons/ha with frequency microorganism local of banana weevil 1 time.
\end{abstract}

Keywords: Banana weevil; compost of rice straw; microorganism local; yield; strawberry.

\section{Pendahuluan}

Stroberi merupakan salah satu komoditas buah yang berpotensi tinggi untuk dikembangkan di Indonesia karena harganya yang mahal dan dapat dibuat berbagai olahan yang disukai banyak orang. Penerapan pertanian organik pada tanaman stroberi sangat menjanjikan karena dapat menghasilkan buah yang lebih sehat dan lebih ramah lingkungan. Pupuk organik mengandung banyak bahan organik yang bermanfaat bagi tanah. Pupuk organik kurang diminati karena sifatnya yang lama tersedia bagi tanah, sehingga perlu didukung proses dekomposisinya agar cepat tersedia bagi tanah. Pengomposan dapat dilakukan dengan penambahan Mikroorganisme Lokal (MOL) untuk mempercepat dekomposisi, memperbaiki mutu kompos, dan menambah unsur hara dalam tanah (Pratiwi dkk., 2013). Bonggol pisang merupakan bahan dasar MOL yang mudah didapat dan murah harganya. Kelebihan dari MOL bonggol pisang yaitu mengandung zat pengatur tumbuh giberelin dan sitokinin yang dapat membantu pembelahan sel tanaman, mikroba pelarut phospat, mikroba pengurai selulosa, dan mudah 
N.H. Fauziyah, S. Budiyanto dan A.D. Sudarman / Buana Sains Vol 20 No 1 : 29-40

didapatkan dengan biaya murah (Parlinah dan Hidayat, 2016). Tujuan dari penelitian ini yaitu mengkaji pengaruh interaksi antara perlakuan dosis pupuk kompos jerami padi dengan frekuensi pemberian MOL bonggol pisang terhadap pertumbuhan dan produksi tanaman stroberi.

\section{Metode Penelitian}

Penelitian dilaksanakan pada bulan September 2019 - Januari 2020 di lahan KBH Karanggeneng, Gunungpati dan Laboratorium Ekologi dan Produksi Tanaman serta Laboratorium Ekologi dan Produksi Tanaman, Fakultas Peternakan dan Pertanian, Universitas Diponegoro, Semarang. Penelitian ini dilakukan menggunakan RAL pola Faktorial 3 x 3 dengan 3 ulangan. Faktor pertama yaitu dosis pupuk kompos, yang terdiri dari tiga taraf, yaitu 15 ton/ha (P1), 20 ton/ha (P2), dan 25 ton/ha (P3). Faktor kedua adalah frekuensi pemberiaan MOL bonggol pisang yaitu diberikan sekali pada umur 7 HST (M1), tiga kali pada umur 7, 21, 35 HST (M2) dan lima kali pada umur 7, 21, 35, 49, 63 HST (M3). Parameter yang diamati berat volume tanah, porositas tanah, kadar air tanah, $\mathrm{pH}$ tanah, bahan organik tanah, tinggi tanaman, jumlah daun, jumlah bunga, jumlah buah, bobot buah. Data yang diperoleh dianalisis secara statistik menggunakan ANOVA untuk mengetahui pengaruh perlakuan dan apabila ada pengaruh nyata dilanjutkan dengan uji jarak berganda DMRT pada taraf $5 \%$ untuk melihat beda antar perlakuan.

Tahapan penelitian antara lain pembuatan kompos jerami padi, pembuatan MOL bonggol pisang, persiapan lahan, penanaman, pemeliharaan, pemanenan, dan pengamatan. Pembuatan kompos dilakukan dengan mencacah jerami padi kering, kemudian dicampur dengan pupuk kotoran sapi $1: 1$. Setelah itu ditambahkan larutan dekomposer EM4 secara berkala selama satu bulan. Adapun pembuatan MOL bonggol pisang dilakukan dengan mencacah bonggol pisang seberat $1 \mathrm{~kg}$ kemudian dimasukkan ke dalam ember. Selanjutnya ditambahkan dengan 200 gram gula merah yang telah dihaluskan dengan 2 liter air cucian beras kemudian diaduk hingga rata. Kemudian ember plastik ditutup rapat dan difermentasikan selama 15 hari. Untuk persiapan lahan, pengaplikasian pupuk kompos, penanaman, dan pengaplikasian MOL. Stroberi varietas California ditanam dengan jarak tanam $30 \times 40 \mathrm{~cm}$. untuk tanah yang telah diolah kemudian dibuat bedengan dengan ukuran panjang $\times$ lebar yaitu $1,6 \times 1,8 \mathrm{~m}$, tinggi $30-40 \mathrm{~cm}$, jarak antar bedengan $60 \mathrm{~cm}$. Pengaplikasian kompos jerami dilakukan 1 minggu sebelum tanam pada lahan yang telah diolah. Lakukan pemberian MOL bonggol pisang sesuai perlakuan sebesar $11,52 \mathrm{ml}$ per bedengan yang dibagi untuk di aplikasikan sekali, tiga kali, dan 5 kali.

\section{Hasil dan Pembahasan}

\section{Berat Volume Tanah}

Hasil analisis ragam menunjukkan bahwa perlakuan dan interaksi antara dosis pupuk kompos dan frekuensi pemberian MOL bonggol pisang berpengaruh nyata terhadap berat volume tanah. Berat volume tanah akibat perlakuan kompos jerami padi dan frekuensi pemberian MOL bonggol pisang disajikan pada Tabel 1. 
N.H. Fauziyah, S. Budiyanto dan A.D. Sudarman / Buana Sains Vol 20 No 1 : 29-40

Tabel 1. Berat Volume Tanah pada Dosis Kompos dan Frekuensi MOL Bonggol Pisang

\begin{tabular}{ccccc}
\hline \multirow{2}{*}{ Dosis Kompos } & \multicolumn{3}{c}{ Frekuensi MOL Bonggol Pisang } & \multirow{2}{*}{ Rata - Rata } \\
\cline { 2 - 3 } & 1 kali & 3 kali & 5 kali & \\
15 ton/ha & $1,0012^{\text {ab }}$ & $1,0590^{\mathrm{a}}$ & $0,9761^{\mathrm{b}}$ & $1,0121^{\mathrm{b}}$ \\
$20 \mathrm{ton} / \mathrm{ha}$ & $1,0532^{\mathrm{a}}$ & $0,9597^{\mathrm{b}}$ & $1,0142^{\mathrm{ab}}$ & $1,0090^{\mathrm{b}}$ \\
$25 \mathrm{ton} / \mathrm{ha}$ & $1,0014^{\mathrm{b}}$ & $1,0542^{\mathrm{a}}$ & $1,0141^{\mathrm{ab}}$ & $1,0232^{\mathrm{a}}$ \\
\hline Rata - Rata & $1,0186^{\mathrm{b}}$ & $1,0243^{\mathrm{a}}$ & $1,0015^{\mathrm{c}}$ & \\
\hline
\end{tabular}

Keterangan: Bilangan yang didampingi oleh huruf yang sama pada kolom yang sama berarti tidak berbeda nyata berdasarkan uji DMRT pada taraf 5\%.

Berat volume tanah akan meningkat seiring peningkatan dosis kompos jerami, dan akan meningkat kemudian turun kembali seiring peningkatan frekuensi pemberian MOL bonggol pisang. Berat volume tanah pada pemberian kompos jerami pada dosis 15 ton/ha $\left(1.012 \mathrm{~g} / \mathrm{cm}^{3}\right)$ sama dengan 20 ton $/ \mathrm{ha}\left(1,009 \mathrm{~g} / \mathrm{cm}^{3}\right)$ tetapi lebih rendah dari 25 ton/ha $\left(1,023 \mathrm{~g} / \mathrm{cm}^{3}\right)$. Berat volume tanah pada perlakuan pemberian MOL bonggol pisang yang diberikan sekali $\left(1.0186 \mathrm{~g} / \mathrm{cm}^{3}\right)$ lebih rendah dibandingkan yang diberikan 3 kali $\left(1,0243 \mathrm{~g} / \mathrm{cm}^{3}\right)$ tetapi lebih tinggi dibandingkan yang diberikan 5 kali $\left(1,0015 \mathrm{~g} / \mathrm{cm}^{3}\right)$. Perubahan berat volume tanah akibat perlakuan dosis kompos jerami padi dan frekuensi pemberian MOL bonggol pisang disajikan pada gambar 1.

Peningkatan dosis pupuk kompos jerami padi dan frekuensi pemberian MOL bonggol pisang akan meningkatkan berat volume tanah secara kuadratik yaitu pada frekuensi pemberian MOL bonggol pisang 1 kali memiliki persamaan yaitu $\mathrm{Y}$ $=-0,00519 X^{2}+0,2077 X+0,8454$, pada frekuensi pemberian 3 kali memiliki persamaan $\mathrm{Y}=0,0969 \mathrm{X}^{2}+0,39 \mathrm{X}+$ 1,3521, sedangkan pada frekuensi pemberian 5 kali memiliki persamaan $\mathrm{Y}$ $=-0,0191 \mathrm{X}^{2}+0,0954+0,8998$. Nilai minimal berat volume tanah dicapai frekuensi pemberian MOL bonggol pisang 3 kali dengan dosis kompos 15 ton/ha yaitu 1,0590. Diduga bahwa pendekomposisian bahan organik pada dosis tersebut dengan frekuensi pemberian bertahap dapat mempercepat dekomposisi tanah sehingga berat voumenya menurun. Hal ini dikarenakan penambahan kompos yang berlebihan tidak semuanya dapat diurai oleh mikroba tanah sehingga akan meningkatkan berat volume tanah. Diduga kompos jerami padi belum terdekomposisi karena proses yang lama sebab kandungan lignin, hemiselulosa dan selulosanya yang tinggi. Lama dekomposisi suatu senyawa pada bahan organik berbeda-beda dari paling cepat yaitu gula, protein, hemiselulosa, selulosa, dan kemudian lignin. Berat volume tanah yang rendah menunjukkan bahan organiknya tinggi dan semakin optimalnya fungsi asam humat yang dihasilkan oleh proses dekomposisi sehingga agregasi tanah semakin mantap. Hal ini sesuai dengan pernyataan Intara dkk. (2011) yang menyatakan bahwa pemberian bahan organik berupa pupuk organik dapat meningkatkan senyawa asam humat dalam tanah sehingga menurunkan berat volume tanah. 


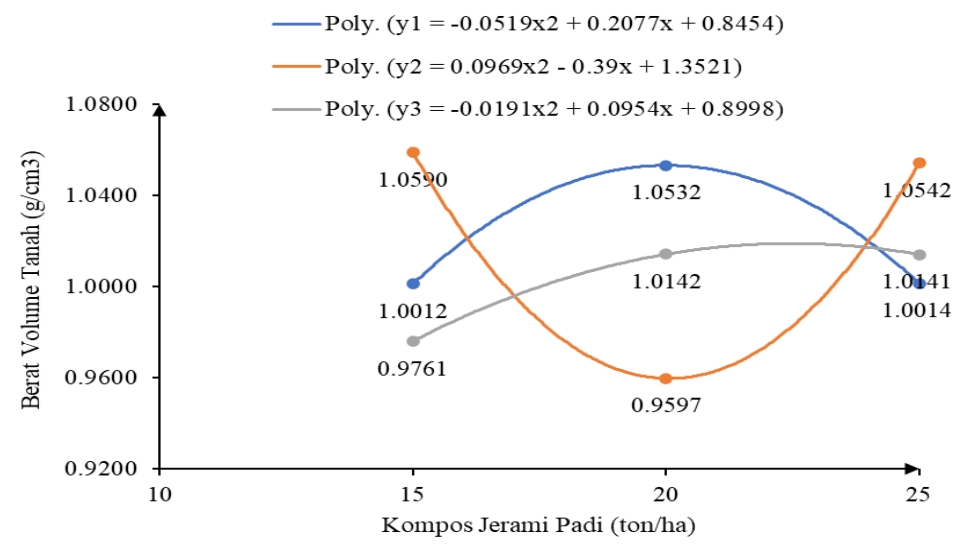

Gambar 1. Berat Volume tanah akibat perlakuan kompos jerami padi dan frekuensi pemberian MOL bonggol pisang

\section{Porositas Tanah}

Hasil analisis ragam menunjukkan bahwa terdapat interaksi antara perlakuan dosis pupuk kompos dan frekuensi pemberian MOL bonggol pisang terhadap porositas tanah. Kedua taraf perlakuan berpengaruh nyata terhadap porositas tanah. Nilai porositas tanah akibat perlakuan kompos jerami padi dan frekuensi pemberian MOL bonggol pisang disajikan pada Tabel 2 .

Porositas tanah akan meningkat dan kemudian menurun seiring peningkatan dosis kompos jerami dan frekuensi pemberian MOL bonggol pisang. Porositas tanah pada pemberian kompos jerami pada dosis 15 ton/ha $(54,1 \%)$ sama dengan 20 ton/ha $(55,8$ $\%$ ) tetapi lebih rendah dari 25 ton/ha $(53,6 \%)$. Porositas tanah akan meningkat dan turun kembali seiring peningkatan frekuensi pemberian MOL bonggol pisang. Porositas tanah pada pemberian MOL bonggol pisang sekali (54,7\%) lebih rendah dari pemberian MOL bonggol pisang 3 kali (54,9\%), namun lebih tinggi dari pemberian $\mathrm{MOL}$ bonggol pisang 5 kali (53,8\%). Perubahan porositas tanah akibat perlakuan dosis kompos jerami padi dan frekuensi pemberian MOL bonggol pisang disajikan pada gambar 2 .

Tabel 2. Nilai Porositas Tanah pada Dosis Kompos dan Frekuensi MOL Bonggol Pisang

\begin{tabular}{|c|c|c|c|c|}
\hline \multirow{2}{*}{ Dosis Kompos } & \multicolumn{3}{|c|}{ Frekuensi MOL Bonggol Pisang } & \multirow{2}{*}{ Rata - Rata } \\
\hline & 1 kali & 3 kali & 5 kali & \\
\hline \multicolumn{5}{|c|}{ - } \\
\hline 15 ton $/$ ha & $55,2^{\mathrm{ab}}$ & $52,0^{\mathrm{bc}}$ & $55,0^{\mathrm{ab}}$ & $54,1^{\text {a }}$ \\
\hline 20 ton/ha & $54,8^{\mathrm{ab}}$ & $57,8^{\mathrm{a}}$ & $54,9^{\mathrm{ab}}$ & $55,8^{\text {a }}$ \\
\hline 25 ton $/$ ha & $54,1^{\mathrm{bc}}$ & $55,0^{\mathrm{ab}}$ & $51,6^{\mathrm{c}}$ & $53,6^{\mathrm{b}}$ \\
\hline Rata - Rata & $54,7^{\mathrm{b}}$ & $54,9^{a}$ & $53,8^{c}$ & \\
\hline
\end{tabular}

Keterangan: Bilangan yang didampingi oleh huruf yang sama pada kolom yang sama berarti tidak berbeda nyata berdasarkan uji DMRT pada taraf 5\%. 
N.H. Fauziyah, S. Budiyanto dan A.D. Sudarman / Buana Sains Vol 20 No 1 : 29-40

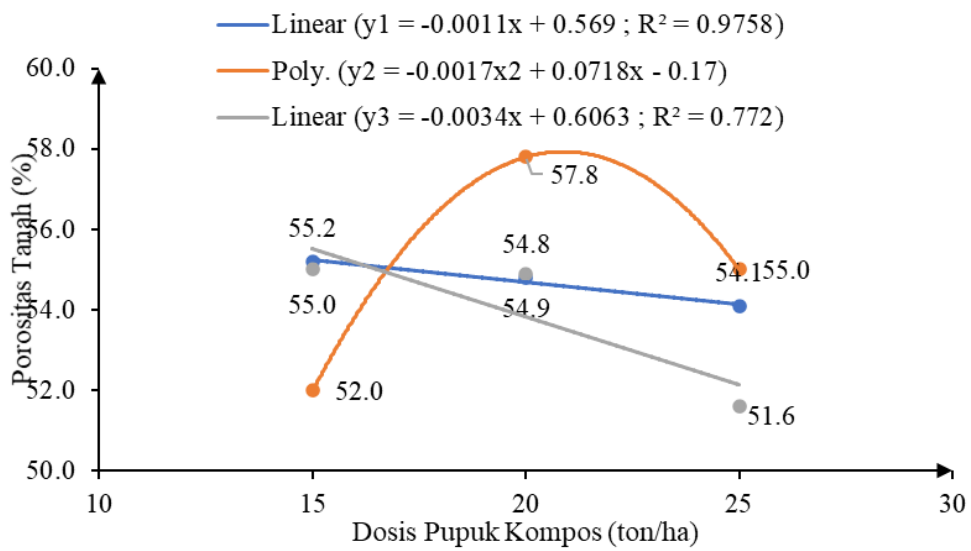

Gambar 2. Porositas tanah akibat perlakuan kompos jerami padi dan perlakuan frekuensi pemberian MOL bonggol pisang

Peningkatan dosis pupuk kompos jerami padi dan frekuensi pemberian MOL bonggol pisang akan meningkatkan porositas tanah. Pada frekuensi pemberian MOL bonggol pisang 1 kali memiliki persamaan linear yaitu $\mathrm{Y}=$ $0,0011 X+0,569\left(R^{2}=0,9758\right)$. Pada frekuensi pemberian MOL bonggol pisang 3 kali memiliki persamaan kuadratik yaitu $\mathrm{Y}=-0,0017 \mathrm{X}^{2}+0,0718$ $\mathrm{x}$ - 0,17. Pada frekuensi pemberian MOL bonggol pisang 5 kali memiliki persamaan linear yaitu $\mathrm{Y}=-0,0034 \mathrm{X}+$ $0,6063\left(R^{2}=0,772\right)$. Interaksi perlakuan dengan hasil terbaik yaitu pada frekuensi pemberian MOL bonggol pisang 3 kali dengan dosis kompos 20 ton/ha dengan hasil porositas tanah sebesar 57,8 \%. Hal ini disebakan karena peningkatan bahan organik akan mendorong peningkatan porositas tanah. Tanah yang porositasnya lebih tinggi menunjukkan pori pada tanah besar dan mengandung bahan organik. Pori-pori tanah yang besar menandakan aerasi dan drainase tanah sangat baik. Hal ini didukung oleh Zulkarnain et al. (2013) yang menyatakan bahwa bahan organik yang ada pada berbagai pupuk organik dapat mengikat pertikel tanah, memperbaiki agregat tanah, meningkatkan porositas tanah dan menurunkan berat isi tanah. Tanah yang porositasnya baik adalah tanah yang porositasnya besar karena mempermudah perakaran mencari bahan organik. Porositas tanah yang tinggi menunjukkan berat volume dan berat jenis yang rendah, kondisi tanah tersebut menunjukkan tingginya bahan organik pada tanah. Semakin rendah berat volume dan berat jenis tanah maka makin banyak kandungan bahan organik pada tanah tersebut. Hal ini sesuai dengan pernyataan dari Muyassir et al. (2012) yang menyatakan bahwa dekomposisi bahan organik pada tanah berakibat pada penurunan berat volume dan berat jenis tanah sehingga struktur tanah lebih remah dan porositasnya tinggi.

\section{Bahan Organik Tanah}

Hasil analisis ragam yang dilakukan menunjukkan bahwa perlakuan interaksi antara dosis pupuk kompos dan perlakuan frekuensi MOL bonggol pisang tidak berpengaruh nyata terhadap kadar c-organik tanah. Kadar C organik tanah akibat perlakuan kompos jerami padi dan frekuensi pemberian MOL bonggol pisang disajikan pada Tabel 3 . 
N.H. Fauziyah, S. Budiyanto dan A.D. Sudarman / Buana Sains Vol 20 No 1 : 29-40

Tabel 3. Kadar C-Organik Tanah pada Dosis Kompos dan Frekuensi MOL Bonggol Pisang

\begin{tabular}{ccccc}
\hline \multirow{2}{*}{ Dosis Kompos } & \multicolumn{3}{c}{ Frekuensi MOL Bonggol Pisang } & \multirow{2}{*}{ Rata - Rata } \\
\cline { 2 - 3 } & 1 kali & 3 kali & 5 kali & \\
\cline { 2 - 3 } 15 ton/ha & 8,17 & 8,00 & 8,38 & 8,18 \\
20 ton/ha & 8,24 & 9,51 & 9,74 & 9,16 \\
25 ton/ha & 8,43 & 9,09 & 10,58 & 9,36 \\
\hline Rata - Rata & 8,28 & 8,86 & 9,57 & \\
\hline
\end{tabular}

Berdasarkan Tabel 3. kandungan bahan organik tanah pada semua taraf perlakuan dosis pupuk kompos jerami padi dan frekuensi pemberian MOL bonggol pisang nilainya sama, yaitu masing-masing adalah untuk 15 ton/ha, 20 ton/ha, dan 25 ton/ha yaitu 8,18\%, $9,16 \%$, dan 9,36\%. Pada frekuensi pemberian MOL bonggol pisang yaitu masing-masing adalah sekali, 3 kali, dan 5 kali yaitu 8,28\%, 8,86\%, 9,57\%. Perlakuan tidak berbeda nyata diduga karena dosis yang digunakan pada perlakuan kompos dan frekuensi pemberian MOL bonggol pisang telah mampu untuk mendukung proses dekomposisi bahan organik sehingga antar perlakuan tidak terlihat berbeda nyata. Tanah penelitian menunjukkan hasil kerapatan tanah yang rendah dan kadar air yang tinggi, hal ini menunjukkan bahwa terdapatnya kandungan bahan organik pada tanah penelitian. Hal ini didukung oleh beberapa penelitian mutakhir (Muyassir dkek., 2012; Dharmawan dan Samsoedin, 2012) yang menyatakan bahwa dekomposisi bahan organik pada tanah berakibat pada penurunan berat volume dan berat jenis tanah, sehingga struktur tanah lebih remah dan kerapatannya rendah.

\section{Jumlah Daun}

Hasil analisis ragam menunjukkan interaksi antara dosis pupuk kompos dan frekuensi MOL bonggol pisang tidak berpengaruh nyata terhadap jumlah daun stroberi. Perlakuan dosis pupuk kompos berpengaruh nyata terhadap jumlah daun stroberi. Jumlah daun tanaman stroberi akibat perlakuan kompos jerami padi dan frekuensi pemberian MOL bonggol pisang disajikan pada Tabel 4.

Tabel 4. Jumlah daun stroberi pada dosis kompos dan frekuensi mol bonggol pisang

\begin{tabular}{crrrr}
\hline & \multicolumn{2}{c}{ Frekuensi MOL Bonggol Pisang } & Rata - Rata \\
\cline { 2 - 4 } Dosis Kompos & 1 kali & 3 kali & 5 kali & \\
\hline 15 ton/ha & 8,7 & 9,5 & 8,9 & $9,0^{\mathrm{b}}$ \\
20 ton/ha & 9,8 & 9,3 & 9,5 & $9,5^{\mathrm{b}}$ \\
25 ton/ha & 11,1 & 10,9 & 10,5 & $10,8^{\mathrm{a}}$ \\
\hline Rata - Rata & 9,8 & 9,9 & 9,6 & \\
\hline
\end{tabular}

Keterangan: Bilangan yang didampingi oleh huruf yang sama pada kolom yang sama berarti tidak berbeda nyata berdasarkan uji DMRT pada taraf $5 \%$. 
N.H. Fauziyah, S. Budiyanto dan A.D. Sudarman / Buana Sains Vol 20 No 1 : 29-40

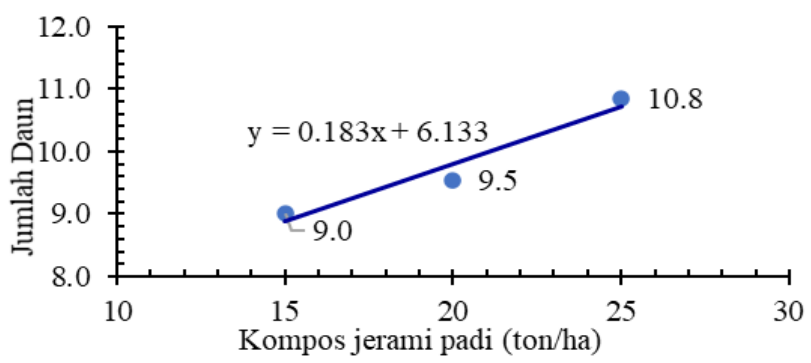

Gambar 3. Jumlah daun stroberi akibat perlakuan kompos jerami padi

Berdasarkan Tabel 4. menunjukkan bahwa jumlah daun stroberi pada semua taraf perlakuan frekuensi pemberian MOL bonggol pisang nilainya sama, yaitu masing-masing adalah untuk frekuensi 1 kali, 3 kali dan 5 kali adalah sebanyak 9,8 helai, 9,9 helai dan 9,6 helai. Hal ini menunjukkan bahwa tidak ada pengaruh dari berapa kali frekuensi aplikasi MOL bonggol pisang terhadap parameter pertumbuhan jumlah daun. Hal ini diduga karena penelitian dilakukan saat musim kemarau sehingga penguapan lebih tinggi. Hal ini didukung oleh pendapat dari Sabaruddin (2012) yang menyatakan bahwa intensitas penyinaran matahari yang tinggi dan terus menerus akan menyebabkan terjadinya evaporasi dan trasnpirasi.

Penambahan dosis kompos jerami padi menyebabkan peningkatan jumlah daun stroberi yaitu dosis 15 ton/ha (9 helai) sama dengan pada dosis 20 ton/ha (9,5 helai) tetapi lebih rendah dari dosis 25 ton/ha (10,8 helai). Perubahan jumlah daun tanaman stroberi akibat perlakuan dosis kompos jerami padi disajikan pada gambar 3 .

Berdasarkan gambar 3, pemberian dosis kompos jerami padi akan meningkatkan jumlah daun stroberi secara linier berdasar persamaan $\mathrm{Y}=$ $0,183 \mathrm{X}+$ 6.133. Penambahan dosis kompos akan meningkatkan jumlah daun. Jumlah daun terbaik terdapat pada perlakuan dosis kompos 25 ton/ha. Hal ini menunjukkan bahwa kompos tersebut memiliki kandungan unsur mikro dan makro yang tinggi sehingga dapat mendukung pertumbuhan vegetatifnya. Hal ini sesuai dengan pernyataan Sumayku et al. (2017) yang menyatakan bahwa pemupukan organik mengandung banyak unsur $\mathrm{N}$ yang berfungsi untuk meningkatkan pertumbuhan vegetatif. Pupuk kompos cocok diaplikasikan saat fase vegetatif tanaman untuk mendukung pertumbuhan vegetatif karena mengandung unsur $\mathrm{N}$ yang tinggi, $\mathrm{P}$ dan $\mathrm{K}$ yang sedang, serta bahan organik yang tinggi.

\section{Jumlah Buah}

Hasil analisis ragam menunjukkan bahwa interaksi antara dosis pupuk kompos dan perlakuan frekuensi MOL bonggol pisang tidak berpengaruh nyata terhadap jumlah buah stroberi. Perlakuan dosis pupuk kompos berpengaruh nyata terhadap jumlah buah tanaman stroberi. Jumlah buah tanaman stroberi akibat perlakuan kompos jerami padi dan frekuensi pemberian MOL bonggol pisang disajikan pada Tabel 5 . 
N.H. Fauziyah, S. Budiyanto dan A.D. Sudarman / Buana Sains Vol 20 No 1 : 29-40

Tabel 5. Jumlah buah stroberi pada dosis kompos dan frekuensi mol bonggol pisang

\begin{tabular}{ccccc}
\hline \hline \multirow{2}{*}{ Dosis Kompos } & \multicolumn{2}{c}{ Frekuensi MOL Bonggol Pisang } & \multirow{2}{*}{ Rata - Rata } \\
\cline { 2 - 3 } & 1 kali & 3 kali & 5 kali & \\
\cline { 2 - 3 } 15 ton/ha & ---0 & 6,3 & 6,0 & $6,7^{\mathrm{b}}$ \\
20 ton/ha & 10,3 & 11,0 & 18,0 & $13,1^{\mathrm{a}}$ \\
25 ton/ha & 16,0 & 17,0 & 13,3 & $15,4^{\mathrm{a}}$ \\
\hline Rata - Rata & 11,4 & 11,4 & 12,4 & \\
\hline
\end{tabular}

Keterangan: Bilangan yang didampingi oleh huruf yang sama pada kolom yang sama berarti tidak berbeda nyata berdasarkan uji DMRT pada taraf 5\%.

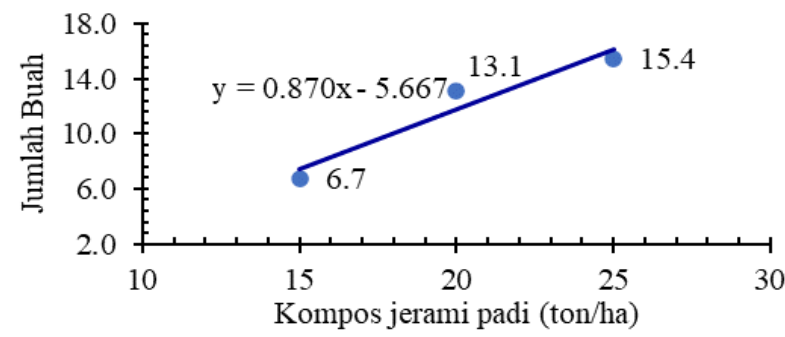

Gambar 4. Jumlah buah stroberi akibat perlakuan pupuk kompos jerami padi

Berdasarkan Tabel 5 jumlah buah stroberi pada semua taraf perlakuan frekuensi pemberian MOL bonggol pisang nilainya sama, yaitu masingmasing frekuensi 1 kali, 3 kali dan 5 kali adalah 11,4 buah, 11,4 buah, dan 12,4 buah. Hasil tersebut menunjukkan bahwa tidak ada pengaruh frekuensi pemberian MOL terhadap jumlah buah tanaman stroberi. Hal ini dapat terjadi karena diduga frekuensi pemberian MOL bonggol pisang 1, 3 dan 5 kali kurang mencukupi kebutuhan unsur hara yang diperlukan saat tahap pertumbuhan. Aplikasi MOL bonggol pisang juga dilakukan saat musim kemarau sehingga rawan terjadi penguapan berlebih yang menyebabkan unsur hara kurang maksimal terserap ke tanaman dan ke tanah.

Penambahan dosis kompos jerami padi meningkatkan jumlah buah stroberi yaitu dosis 15 ton/ha (6,7 buah) lebih rendah daripada dosis 20 ton/ha $(13,1$ buah) yang sama dengan dosis 25 ton/ha (15,4 buah). Perubahan jumlah buah tanaman stroberi akibat perlakuan dosis kompos jerami padi disajikan pada gambar 4.

Berdasarkan gambar 4, perlakuan frekuensi pemberian dosis kompos jerami akan meningkatkan jumlah buah stroberi secara linier berdasar persamaan $\mathrm{Y}=0,87 \mathrm{X}-5,6667\left(\mathrm{R}^{2}=0.9311\right)$. Rata-rata jumlah buah terbaik terdapat pada perlakuan dosis 25 ton/ha yaitu 15,4 buah. Hal ini diduga karena penambahan dosis yang signifikan akan menambah unsur hara kedalam tanah sehingga kandungan unsur hara juga meningkat dan memperbaiki sifat-sifat tanah. Tanah yang baik akan mendukung pertumbuhan tanaman secara langsung serta memudahkan penyerapan nutrisi dari akar tanaman. Pemakaian kompos jerami dalam jangka panjang dapat meningkatkan bahan organik tanah dan mengembalikan kesuburan tanah. Hal ini didukung oleh Muyassir dkk. (2012) bahwa dekomposisi bahan organik pada tanah berakibat pada penurunan berat volume dan berat jenis tanah sehingga struktur tanah lebih remah dan mudah diolah. 
N.H. Fauziyah, S. Budiyanto dan A.D. Sudarman / Buana Sains Vol 20 No 1 : 29-40

\section{Bobot Buah}

Hasil analisis ragam menunjukkan bahwa interaksi antara dosis pupuk kompos dan frekuensi MOL bonggol pisang tidak berpengaruh nyata terhadap bobot buah tanaman stroberi. Kedua perlakuan berpengaruh nyata terhadap bobot buah tanaman stroberi. Bobot buah tanaman stroberi akibat perlakuan kompos jerami padi dan frekuensi pemberian MOL bonggol pisang disajikan pada Tabel 6 .

Hasil uji jarak berganda Duncan menunjukkan bahwa rata-rata bobot buah akan meningkat seiring peningkatan dosis kompos jerami. Bobot buah stroberi pada pemberian kompos jerami pada dosis 15 ton/ha $(1,99 \mathrm{~g})$ meningkat pada dosis 20 ton/ha $(2,44 \mathrm{~g})$ yang sama dengan dosis 25 ton/ha $(2,44 \mathrm{~g})$. Bobot buah akan menurun dan meningkat kembali seiring peningkatan frekuensi pemberian MOL bonggol pisang yaitu sekali $(2,522 \mathrm{~g})$ lebih tinggi daripada 3 kali $(2,107 \mathrm{~g})$ tetapi sama dengan 5 kali $(2,242 \mathrm{~g})$. Perubahan bobot buah stroberi akibat perlakuan dosis kompos jerami padi dan frekuensi pemberian MOL bonggol pisang disajikan pada gambar 5 .

Berdasarkan gambar 5, perlakuan pemberian kompos jerami padi akan mempengaruhi rata-rata bobot buah secara kuadratik berdasar persamaan $\mathrm{Y}=$ - 0,009 $\mathrm{X}^{2}+0.400 \mathrm{X}-2.023 \mathrm{~g} /$ tanaman, dengan titik optimal pada dosis kompos jerami padi 22 ton/ha dengan rata-rata bobot buah $2.42 \mathrm{~g} /$ tanaman. Bahan organik yang tinggi berpengaruh secara signifikan terhadap pertambahan ratarata bobot buah tanaman stroberi. Dekomposisi bahan organik pada tanah berakibat pada penurunan berat volume, sehingga struktur tanah lebih remah dan kerapatannya rendah atau porositasnya meningkat. Tanah yang mengandung bahan organik dan kadar air tinggi memudahkan proses fotosintesis tanaman sehingga mendukung proses pembesaran buah. Hal ini sesuai dengan pernyataan dari Safei dkk. (2014) yang menyatakan bahwa pemupukan menggunakan bahan yang kaya akan bahan organik akan menginisiasi pertumbuhan tanaman seperti pembungaan dan pembuahan.

Perlakuan frekuensi pemberian MOL bonggol pisang akan mempengaruhi bobot buah stroberi secara kuadratik berdasar persamaan $\mathrm{Y}=$ $0.069 \mathrm{X}^{2}-0.482 \mathrm{X}+2,936 \mathrm{~g} /$ tanaman. Perlakuan frekuensi pemberian MOL bonggol pisang 1 kali memberikan hasil bobot buah terbaik yang sama dengan pemberian 5 kali dan lebih tinggi dari perlakuan pemberian 3 kali. Hal ini disebakan karena aplikasi MOL bonggol pisang saat masa generatif dapat mendukung proses pembungaan dan pembentukan buah tanaman stroberi. Perlakuan MOL bonggol pisang satu kali lebih berpengaruh terhadap pertambahan bobot buah stroberi karena MOL mengalami proses dekomposisi bahan organik sehingga saat mulai berbuah, nutrisi langsung dimanfaatkan dalam proses pembesaran buah. MOL bonggol pisang mengandung banyak bakteri pelarut fosfat dan kalium yang mendukung proses pembesaran buah, yaitu Azospirillium, Bacillus, Aeromonas, Aspergillus, mikroba pelarut fosfat, dan mikrobia selulotik. 
N.H. Fauziyah, S. Budiyanto dan A.D. Sudarman / Buana Sains Vol 20 No 1 : 29-40

Tabel 6. Bobot buah stroberi pada dosis kompos dan frekuensi mol bonggol pisang

\begin{tabular}{ccccc}
\hline \hline & \multicolumn{2}{c}{ Frekuensi MOL Bonggol Pisang } & Rata - Rata \\
\cline { 2 - 3 } Dosis Kompos & 1 kali & 3 kali & 5 kali & \\
\cline { 2 - 3 } 15 ton/ha & 2,01 & 1,99 & 1,96 & $1,99^{\mathrm{b}}$ \\
20 ton/ha & 2,73 & 2,14 & 2,45 & $2,44^{\mathrm{a}}$ \\
25 ton/ha & 2,83 & 2,19 & 2,32 & $2,44^{\mathrm{a}}$ \\
\hline Rata - Rata & $2,52^{\mathrm{a}}$ & $2,11^{\mathrm{b}}$ & $2,24^{\mathrm{ab}}$ & \\
\hline
\end{tabular}

Keterangan: Bilangan yang didampingi oleh huruf yang sama pada kolom yang sama berarti tidak berbeda nyata berdasarkan uji DMRT pada taraf 5\%.

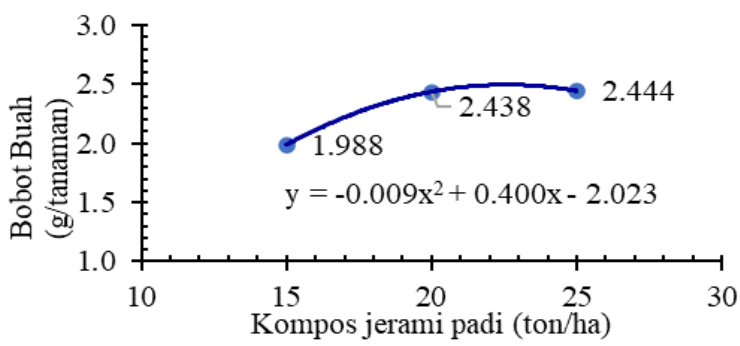

(a)

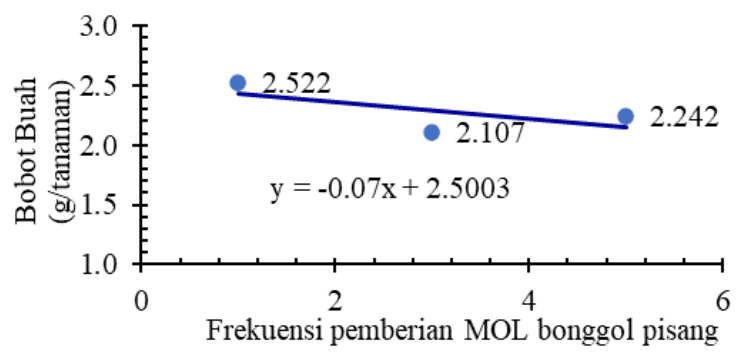

(b)

Ilustrasi 5. Bobot buah Strawberi akibat (a) perlakuan kompos jerami padi dan (b) frekuensi pemberian MOL bonggol pisang

\section{Kesimpulan}

Berdasarkan hasil penelitian dapat disimpulkan bahwa perlakuan dosis kompos dan frekuensi pemberian MOL bonggol pisang akan memperbaiki sifatsifat tanah (berat volume, porositas, kadar air, $\mathrm{pH}$ dan bahan organik), perbaikan sifat tanah optimal terjadi pada dosis kompos antara 20 sampai 30 ton/ha, dan frekuensi pemberian sebanyak 2 kali pemberian. Perlakuan pemberian kompos akan meningkatkan parameter jumlah daun, jumlah bunga, sedangkan untuk jumlah buah dan bobot buah optimal terjadi pada dosis 20 ton/ha.

\section{Daftar Pustaka}

Balasubramaniam, M. K. 2013. Potential utilization of rice straw for ethanol production by sequential fermentation of cellulose and xylose using Saccharomyces cerevisiae and Pachysolen tannophilus. International Journal of Science, Engineering and Technology Research (IJSETR) 2 (7) : 2278 - 7798.

Balitjestro. 2015. Budidaya Stroberi (Fragaria $\mathrm{x}$ ananassa). Peneliti Balai Penelitian Tanaman Jeruk dan Buah Subtropika. Badan Penelitian dan Pengembangan Pertanian.

Dharmawan, I. W. S., dan I. Samsoedin. 2012. Dinamika potensi biomassa karbon pada lanskap hutan bekas tebangan di hutan penelitian Malinau. Jurnal Penelitian Sosial dan Ekonomi Kehutanan. 9 (1) : $12-20$.

Haryadi, D., H. Yetti., S. Yoseva. 2015. Pengaruh pemberian beberapa jenis pupuk terhadap pertumbuhan dan produksi tanaman kailan (Brassica alboglabra L.). Jom Faperta 2 (2): 1 - 10. 
N.H. Fauziyah, S. Budiyanto dan A.D. Sudarman / Buana Sains Vol 20 No 1 : 29-40

Inrianti., S. Tuhuteru., S. Paling. 2019. Pembuatan mikroorganisme lokal bonggol pisang pada kelompok tani tunas harapan distrik Walelagama, Jayawijaya, Papua. J. Ilmiah Pengabdian kepada Masyarakat 5 (3) : 188 - 194.

Intara, Y. I., A. Sapei., Erizal., N. Sembiring., M. H. B. Djoefrie. 2011. Pengaruh pemberian bahan organik pada tanah liat dan lempung berliat terhadap kemampuan mengikat air. J. Ilmu Pertanian Indonesia 16 (2) : 130 135.Isroi. 2008. Kompos. Balai Penelitian Bioteknologi Perkebunan Indonesia, Bogor.

Ni'matillah, Z. A., H. Ashari., R. Soelistyono., N. Herlina. 2014. Pengruh macam bahan tanam pada pertumbuhan dan hasil tiga varietas stroberi (Fragaria sp.). Jurnal Produksi Tanaman 2 (2) : 162 171.

Pane, M. A., M. M. B. Damanik., B. Sitorus. Pemberian bahan organik kompos jerami padi dan abu sekam padi dalam memperbaiki sifat fisik kimia tanah ultisol serta pertumbuhan tanaman jagung. J. Online Agroekoteknologi 2 (4) : 1426 - 1432.

Parlinah, L., dan O. Hidayat. 2016. Mikroorganisme Lokal dalam pengomposan pada mutu lobak var greenbow yang dipanen berbeda. Paspalum 4 (1) : 40 - 48.

Pratiwi, I. G. A. P., I. W. D. Atmaja, dan N. N. Somniari. 2013. Analisis kualitas kompos limbah persawahan dengan MOL sebagai dekomposer. J. Agroekoteknologi Tropika, 2(4) : 195 - 203.

Ramli., A. K. Palolong., U. A. Rajamuddin. 2016. Perubahan sifat fisik tanah akibat pemberian pupuk kandang dan mulsa pada pertanaman terung ungu (Solanum melongena L.), entisol, Tondo Palu. J. Agrotekbis 4 (2) : 160 167.

Sabaruddin, L. 2012. Agroklimatologi. Penerbit Alfabeta. Bandung.

Sartohadi, J., Suratman., Jamulya., N. I. Sari. 2014. Pengantar Geografi Tanah (Cetakan III). Penerbit Pustaka Pelajar. Yogyakarta.

Safei, M., A. Rahmi., N. Jannah. 2014. Pengaruh jenis dan dosis pupuk organik terhadap pertumbuhan dan hasil tanaman terung (Solanum melongena L.) varietas mustang F1. J. Agrifor 8 (1) : 59 - 66.

Sumayku, B. R. A., T. Wardiyati., A. Afandi., J. P. Mandang. 2017. Aplikasi teknologi budidaya ramah lingkungan terhadap kualitas buah stroberi. Eugenia 23 (1) : 1 - 8 .

Zulkarnain, M., B. Prasetya., Soemarno. 2013. Pengaruh kompos, pupuk kandang, dan custom-bio terhadap sifat tanah, pertumbuhan dan hasil tebu (Saccharum officinarum L.) pada entisol di kebun NgrangkahPawon, Kediri). Indonesian Green Technology Journal 2 (1) : $45-52$. 
